\title{
Exploring the role of morphemes in word reading
}

\author{
JOANNE F. CARLISLE \\ C. ADDISON STONE \\ University of Michigan, Ann Arbor, USA
}

heories of what is involved in learning to read English must take into account that the English language is morphophonemic. The spelling system is based on both representations of sounds (phonemes) and units of meaning (morphemes). In recent years, researchers have contributed much to our understanding of the role of phonemic awareness in the development of word-reading skill. Although studies have shown that morphological awareness is also related to word reading (e.g., Carlisle, 2000; Fowler \& Liberman, 1995; Singson, Mahoney, \& Mann, 2000), the role of morphology in learning to read is not well understood. Verhoeven and Perfetti (2003) stated,

How children learn to recognize more complex words on the basis of their constituent parts remains to be established. Although children perceive speech and recognize words, there is nothing in that ability that makes visible the composition of speech in terms of morphological constituents. Some morphological awareness seems to be required for children to be successful in reading. (p. 211)

Presumably, researchers and educators would benefit from understanding aspects of morphemic structure that affect word reading for students who are acquiring reading skill. Such understanding might help educators determine whether morphemic structure deserves a place in the word-study curriculum and, if so, at what grade levels.

\section{Morphemes in models of word-reading acquisition}

Models of factors involved in acquiring word-reading skill (i.e., the ability to pronounce written words) tend to focus primarily on the establishment of connections between the letters (orthography) and sounds (phonology) in words. In the models proposed by Ehri (1998) and Perfetti (1992), for example, children develop increasingly strong connections between phonological and orthographic characteristics 
TWO STUDIES were designed to investigate the role of morphemic structure on students' word reading. The first study asked whether familiar morphemes in words facilitate word reading for elementary students. Results showed that lower and upper elementary students read words with two morphemes (derived words with a base word and one suffix, such as shady) faster than words with one morpheme (e.g., lady). The second study was designed to investigate the effects of phonological transparency on middle and high school students' reading of derived words. Results showed that phonologically transparent words, words in which a base form is intact in the pronunciation of the derived word (e.g., classic in classical), were recognized and read faster than derived words that are less phonologically transparent (e.g., colonial), pinpointing an aspect of morphemic structure that affects reading derived words. The results indicate that reading derived words is not accomplished solely by familiarity with letter-sound associations or syllables; morphemes also play a role. Results also suggest value in emphasizing morphemic structure in models of word-reading acquisition.

SE DISENAARON dos estudios para investigar el papel de la estructura morfémica en la lectura de palabras. En el primer estudio se exploró si la presencia de morfemas familiares en las palabras facilitaba la lectura en estudiantes de escuela primaria. Los resultados mostraron que tanto los estudiantes del primer ciclo, como los del segundo ciclo de primaria leyeron con mayor rapidez palabras de dos morfemas (palabras derivadas con una base y un sufijo, e.g. shady) que palabras de un morfema (e.g. lady). El segundo estudio se diseñó para investigar el efecto de la transparencia fonológica durante la lectura de palabras derivadas en estudiantes de escuela media y superior. Los resultados mostraron que las palabras fonológicamente transparentes, palabras en las que la forma base permanece intacta en la pronunciación de la palabra derivada (e.g. classic en classical), se reconocieron y leyeron más rápido que palabras derivadas con menor transparencia fonológica (e.g. colonial). Ello apunta al hecho de que la estructura morfémica afecta la lectura de las palabras derivadas. Los resultados indican que en la lectura de palabras derivadas no interviene sólo la familiaridad con las asociaciones letra-sonido o sílabas; también los morfemas juegan un papel. Asimismo los resultados sugieren el valor de dar importancia a la estructura morfémica en los modelos de adquisición de la lectura.

ZWEI STUDIEN wurden entworfen, um die Rolle morphemischer Strukturen beim Wörterlesen der Schüler zu untersuchen. Die erste Untersuchung befragte, ob die in Worten bereits bekannten Morpheme das Lesen von Wörtern für Schüler der Grundstufen erleichtern. Die Ergebnisse zeigten, daß die Unterstufen- und höherstufigen Grundschüler die Wörter mit zwei Morphemen (abgeleitete Wörter mit einem Basiswort und einer Endung, wie shady bzw.schattig) schneller lesen als Wörter mit nur einem Morphem (z.B. ladybzw. Dame). Die zweite Studie war darauf ausgerichtet, die Auswirkungen phonologischer Transparenz bei Mittel- und Oberschülern im Lesen von abgeleiteten Wörtern zu untersuchen. Die Ergebnisse zeigten, daß phonologisch transparente Wörter, Worte in denen die Basisform innerhalb der Aussprache des abgeleiteten Wortes intakt bleibt (z.B. classic in classical), schneller erkannt und gelesen wurden als abgeleitete Wörter mit geringerer phonologischer Transparenz (z.B. colonial), unter Hinweis auf einen Aspekt morphemischer Struktur, welcher das Lesen von abgeleiteten Wörtern beeinflußt. Die Ergebnisse zeigen, daß das Lesen von abgeleiteten Wörtern nicht ausschließlich aufgrund deren Vertrautheit von Buchstaben-Lautassoziationen oder Silben erreicht wird; Morpheme spielen ebenfalls eine Rolle. Die Resultate schließen auf die Bedeutung der Hervorhebung morphemischer Strukturen in Anwendungsmodellen des Lesens von Wörtern.

\section{ABSTRACTS}

Exploring the role of morphemes in word reading

\section{Explorando el papel de los morfemas en la lectura de palabras}

\section{Untersuchung}

der Rolle von Morphemen beim Lesen von Wörtern 
Exploration du rôle des morphèmes dans la lecture de mots

\section{Исследование роли морфем при чтении отдельных слов}

\section{单語の読みにおける形態素の役割の探求}

生徒の単語の読みに掞ける形態素構造の役割を調査するために、2つの研究がデザインされ た。1つ目の研究では、語中のありふれた形態素によって、小学生の単語の読みが容易にな るかどうかが問うれた。結果、小学校低学年亡高学年の生徒達が、1つの形態素を持つ語

(例、lady)より 2 つの形態素を持つ語（例、shadyのような語基と接星辞 1 つを持つ派生語） を早く読んだことが明らかになった。2つ目の研究は、中高生の派生語の読みへの音韻的透 明性の影響を調査するためにデザインされた。結果、音韻的に透明な語、即ち派生語の発音 において語基の形が不変である語（例、classicalにおける classic）が、音韻的により不透明 である派生語（例、colonial）より早く認識され読まれたことが明らかになり、派生語の読み に影響する形態素構造の一面が正確に示された。こうした結果によって、派生語の読みは、 文字と音のつながりや音節との慣れによってのみ達成されるのではなく、形態素にも役割が あることが示唆される。また、その結果によって、単語の読みの習得モデルにおいて形態素 構造を強調することの有用性が示唆される。

ON A réalisé deux études pour étudier le rôle de la structure morphémique sur la lecture de mots des élèves. La première étude s'est demandée si la présence de morphèmes familiers dans des mots facilite la lecture de ces mots par des élèves d'école primaire. Les résultats montrent que les élèves des grandes et des petites classes d'école primaire lisent les mots comportant deux morphèmes (mots dérivés comportant un mot de base et un suffixe, tel que shady) plus vite que des mots n'ayant qu'un seul morphème (par exemple, lady). La seconde étude a été réalisée pour étudier les effets de la transparence phonologique sur la lecture de mots dérivés par des élèves de collège et de lycée. Les résultats ont montré que les mots transparents phonologiquement, mots dans lesquels la forme de base est la même lors de la prononciation du mot dérivé (par exemple, classic dans classical) sont reconnus et lus plus vite que des mots dérivés qui sont moins transparents phonologiquement (par exemple, colonial), ce qui met en évidence un aspect de la structure morphologique qui affecte la lecture de mots dérivés. Les résultats indiquent que la lecture de mots dérivés ne dépend pas seulement de la familiarité des associations grapho-phonétiques ou des syllabes mais que les morphèmes aussi jouent un rôle. Les résultats soulignent aussi l'intérêt de mettre l'accent sur la structure morphémique dans les modèles d'acquisition de la lecture des mots.
Аля исслслования роли, которую морфологическая сгруктура слов итрает ири их чтении, было ирелгринято Ава исследования. Целыю первого было ироверить, летче яи учанимся пачалыной пиколы читать те слова, гле встречаются зиакомые морфемы. Результаты иоказали, что и

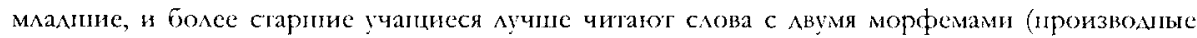
слова, состояцие из корня основного слова и олното суффикса, панример shadj), чем слова с омной морфемой (например, ladj). Цель второго исслелонания: изучить, как вАияе' фонолотическая прозрачносгь ироизволных слов на их чтение учанимися срслней и старпей пиколы. Результаты пюказали, что фонологически црозрачныс слова, то ссть те, в которых основа остается сохрангой в произнопении произволного слова (напримср, classic в

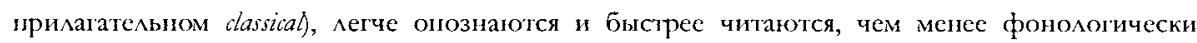
шрозрачные производные слова (например, colonial). Это подчеркивает особую роль, которую играет морфологичсская сгрукгура произволных слов в их чтении. Результаты Аемопстрируют, что чтснис произволных слов ІІроИсхолит не только на оспове звуко-буквенных связей или Асления на слоги; морфемы также имеют значенис. ПІолучснные выводы позволяют рекоменловать изучсние морфологической структуры слова в качестве составлянцей различных молслей освосиия навыков чтения. 
of words with repeated exposures to written words, and as these links become complete and well established, word recognition becomes more automatic. Forging these connections involves internalizing the statistical regularities in the system of mapping spellings and sounds (see Brown, 1998). Such models include mappings of letter combinations (e.g., st in stop), but there is no particular role for morphemes. However, some morphemes might be processed as common orthographic patterns - that is, without regard for their morphemic identities and their syntactic and semantic functions. For example, in Ehri's model, the last stage is the "consolidated alphabetic phase," during which children are learning patterns of letters that occur frequently together (e.g., est in nest and pest). Ehri suggested that knowing est as a consolidated unit means that the letters and letter sounds have been analyzed and bonded:

"If a reader knew units such as -est, -tion, -in, and -ing as consolidated units, the task of learning longer sight words such as question and interesting would be easier" (p. 23). She did not distinguish between letter patterns that are morphemes and those that are not. Still, it is possible that, because they carry meaning, morphemes might play a somewhat different role in word recognition than syllables or letter combinations.

Adams (1990) acknowledged this possibility. Her model of component processes in word reading included phonological, orthographic, and meaning processors. She proposed that the connection between the orthographic and meaning processors might be "responsible for skilled readers' perceptual sensitivity to the roots or meaning-bearing fragments of polysyllabic words and nonwords" (p. 151). However, she also stated that such awareness is "not very strong" and is a late-developing aspect of word reading. Both Ehri's and Adams's models suggest that letter combinations that are and are not morphemes would not differentially affect word-reading performance of young students.

In a model of word reading and spelling, Schlagal (1992) provided a more explicit account of the influence of word structure on word reading in two stages: the stage at which students are learning to recognize two-syllable words and the subsequent stage at which students are learning complex soundletter relations for syllables (e.g., /shun/ for -tion). Words characteristic of both stages are sometimes morphologically complex as well as multisyllabic; however, no distinction is made in Schlagal's model between syllables and morphemes. In contrast, Seymour's (1997) dual-foundation model distinguishes orthographic and morphographic develop- ment, because English orthography encodes information at both lexical and morphemic levels.

Although models of the acquisition of word reading are not consistent in assigning a role to morphology, current models of adult reading indicate that morphemes are represented in memory (including bound morphemes that cannot stand alone, such as the suffix $-l y$ ) and play a role in word recognition (Schreuder \& Baayan, 1995; Schreuder, Grendel, Poulisse, Roelofs, \& van de Voort, 1990; Taft, 2003; Taft \& Zhu, 1995). In Taft's model, interactive processing of concept, word, and morpheme levels occurs if the reader has mental representations of the constituent morphemes. Such mental representations develop through experiences with both oral and written language. If a person hears or reads graceful but does not know the word or its constituent morphemes (grace and -ful), these morphemes cannot facilitate word identification; instead, submorphemic elements (e.g., syllables, phonemes) would be activated for this purpose. In short, the likelihood that morphemes in a word play a role in word identification is thought to depend on exposure to those morphemes in different word contexts (Reichle \& Perfetti, 2003).

Findings of research studies have provided support for models such as Taft's. They suggest that morphemes function for adults as perceptual units that influence word recognition (e.g., Fowler, Napps, \& Feldman, 1985; Nagy, Anderson, Schommer, Scott, \& Stallman, 1989; Napps, 1989; Stolz \& Feldman, 1995). Nagy et al. found that for derived words (i.e., base words with one or more prefixes or suffixes), the number of words in a word family (i.e., words with the same base morpheme, such as love, lovely, lover, loveliness) and the frequency of words in that family affected adults' speed of recognition of the base word. Thus, frequent encounters with a base word (by itself or combined with affixes in words) reinforce the mental representation of the morphemes in those words, and access to memory for the morphemes speeds identification of words containing those morphemes. The larger a word family, the greater the likelihood that the base word will facilitate recognition of words, even if these words are new to the individual, as perhaps lovenest might be.

\section{Transparency influences morphological processing}

Along with word frequency, the transparency of the structure of a word with more than one morpheme plays a role in word identification (e.g., 
Schreuder \& Baayan, 1995). Two types of transparency are of particular importance for word reading: phonological and orthographic transparency. Phonological transparency means that the pronunciation of the base word is intact in the derived word. For example, growth is phonologically transparent, but health is not, as the pronunciation of heal changes in health. Orthographic transparency means that the spelling of the base word is intact (or mostly so) in the derived word. Thus, the spelling of quickly is transparent, whereas the spelling of decision is not because the base word (decide) is not retained in the spelling of the derived word. (It might be important to add that words are generally considered orthographically transparent when the only change involves the addition of a suffix - for example, when the $e$ in fame is dropped in famous or when $y$ in easy is converted to $i$ in easily.) In oral and written language, phonological transparency affects the ease with which the morphemic structure of a word is recognized (MacKay, 1978). For example, third and fifth graders are more accurate at completing a sentence by forming a phonologically transparent word, such as, "Warm. He chose the jacket for its " than completing a sentence with a word that undergoes a phonological shift, such as "Heal. The man was worried about his " (Carlisle, 2000).

Preliminary evidence suggests that phonological transparency of derived words helps with the recognition of morphemes in words and, in turn, facilitates word reading for adults and school-age students (Carlisle, 2000; Mann \& Singson, 2003). Although students in grades 3 through 6 are more accurate at reading phonologically transparent than opaque derived words, Mann and Singson found a dramatic increase in students' accuracy of reading opaque derived words in grades 4 and 5. With regard to orthographic transparency, English spellings often signal a morphological similarity even when pronunciations change (e.g., profane and profanity) (Templeton \& Scarborough-Franks, 1985). On the basis of a study of 6th- and 10th-grade students' reading and spelling of derived words such as profanity, Templeton and Scarborough-Franks suggested that readers first acquire a tacit awareness of the base words, which is abstracted from exposure to words that contain that base. Awareness of the suffixes and conventions of adding suffixes to base words develops thereafter. Furthermore, they indicated that, because the phonological representation of base words is often not intact in the derived words (e.g., confide, confidence), transparency of the spelling of the base word and suffix might facilitate the reader's awareness of morphemic structure.

To summarize, phonological transparency and orthographic transparency significantly affect awareness of morphemic structure. Students who are learning to read derived words are likely to make use of morphemes that are transparent in sound and spelling, whereas for older readers, orthographic transparency aids in recognition of morphemes in derived words that lack phonological transparency. Collectively, these findings suggest that models of acquisition of word reading might need to take into account the effects of morpheme processing, as well as phonemes and spelling patterns. However, support for this suggestion is needed. Previous studies have shown an association between reading derived words and decoding skill, but they have not provided specific evidence that morphemic structure makes a difference.

\section{Students' reading of derived words}

Findings suggest that students' morphological awareness is related to their reading of derived words (e.g., Carlisle, 2000; Verhoeven, Schreuder, \& Baayan, 2003) and, more generally, to decoding skill (e.g., Fowler \& Liberman, 1995; Singson et al., 2000). Singson et al. reported a correlation of .58 between word reading and morphological awareness. Whereas word reading is predicted by phonological awareness in the first years of school, by fifth grade students' decoding ability is better predicted by morphological than by phonological skills (Mann \& Singson, 2003).

Studies have shown that on both oral tasks and word-reading tasks, student perform better on highfrequency, phonologically transparent derived words than on words that are lower in frequency or that lack phonological transparency (e.g., Carlisle, 2000; Mann \& Singson, 2003). Carlisle found that, in general, fifth graders were significantly better than third graders in reading derived words, but that they were most noticeably better at reading words that lacked phonological transparency (such as natural). Mann and Singson reported similar findings in a study of students in grades 3 to 6 . Confirming the difficulties students have negotiating phonological shifts from base to derived words, they also reported that the younger students tended to pronounce the suffix correctly but to mispronounce the base word. The results of other studies show that poor readers experience particular difficulties recognizing the morphemic structure of words that are not transparent in sound and spelling (Carlisle, Stone, \& Katz, 
2001; Champion, 1997; Leong, 1989; Windsor, 2000), but that they benefit from morphemic structure of transparent words in reading words (Elbro \& Arnbak, 1996). This might be because recognition of high-frequency base words and affixes helps them decode long and seemingly unfamiliar words.

Awareness of morphemic structure becomes particularly important for reading and understanding academic texts after the early elementary years. Nagy et al. (1989) estimated that about $60 \%$ of the unfamiliar words encountered by students in the middle school years and beyond are morphologically complex and sufficiently transparent in structure and meaning so that a reader might be able to read and infer the meaning of the word in context. Inaccurate reading of derived words might contribute to significant problems with text comprehension (e.g., Tyler \& Nagy, 1990). Not surprisingly, morphological awareness and reading derived words are significantly related to reading comprehension by the upper elementary years (Carlisle, 2000; Windsor, 2000).

\section{Purpose of the studies}

In this article, we report two studies designed to investigate students' reading of derived words. The first study focuses on the question of whether morphemes play a role in speed and accuracy of reading derived words. To answer this question, we compared the speed and accuracy of lower (grades 2 and 3 ) and upper (grades 5 and 6) elementary students' reading of two-syllable words that are derived words (e.g., shady) and two-syllable words matched in spelling (e.g., lady) that are made up of one morpheme. We also asked the students to read low-frequency derived words with high-frequency base words (e.g., queendom) in order to determine whether familiarity with the base word influenced speed and accuracy of word reading. All of the words in this study were phonologically and orthographically transparent. Because the results might misrepresent the challenges of reading derived words (the most important of which is phonological transparency), the second study was designed to examine the effects of phonological transparency or lack thereof on the reading of derived words. Influenced by the results of studies by Templeton and Scarborough-Franks (1985) and Mann and Singson (2003), we also sought to determine whether lack of phonological transparency would affect reading of derived words in the middle school years but would not be so apparent by the high school years, when students have sufficient experience with written texts so that they benefit from orthographic cues to morphemic structure.

\section{Study 1}

In this study, we investigated students' reading of transparent derived words; that is, words in which the spelling and the pronunciation of the base form is intact in the derived word (e.g., hill in hilly). Our primary question was whether sensitivity to morphemic structure influenced speed and accuracy of word reading. To determine this, we compared students' reading of phonologically and orthographically transparent derived words with two syllables and two morphemes (e.g., hilly) to their reading of transparent derived words with two syllables and one morpheme (e.g., silly). Matched for spelling and word frequency, the one-morpheme words had the same endings; they looked like derived words, so that we refer to them as pseudoderived words. Because morphemic structure is the only noteworthy distinguishing feature, we reasoned that if performance on derived and pseudoderived words did not differ significantly, we would have support for those models of reading acquisition that give morphemic structure no important role. On the other hand, if derived words were read faster or more accurately, we would have evidence that transparent morphemic structure facilitates word reading in the elementary years.

We also asked students to read low-frequency derived words that had high-frequency base forms, such as queendom. Of particular interest was whether the familiarity of the base word influenced the speed and accuracy of reading unfamiliar derived words. Transparency of structure might play an important role when young readers are faced with decoding unfamiliar words in natural texts. Because by the late elementary years so many of the unfamiliar words in school texts are transparent derived words (Nagy \& Anderson, 1984), decoding unfamiliar derived words becomes increasingly important for successful reading and understanding of school texts. Specifically, Nagy and Anderson found that affixed words outnumber base words by a factor of about 4 to 1 in texts written for grades 3 to 9. Furthermore, high-frequency words (words occurring more than once in a million words) were often base words, but among low-frequency words, affixed words were more common. By fourth grade, the less frequent, affixed words are the majority of unfamiliar words in students' texts. They are also the major contributors to children's vocabulary growth by fifth grade (Anglin, 1993). Students' reading of low-frequency derived words would help us understand the extent to which familiar base words influenced reading of unfamiliar derived words for lower and upper elementary students. 
The research questions were as follows: (a) Do lower and upper elementary students differ in speed and accuracy of reading high-frequency, two-syllable words that are either derived or pseudoderived? (b) Do these groups of students differ in the speed and accuracy of reading low-frequency derived forms? (c) Is reading of high- and low-frequency derived words related to word decoding on a standardized measure for each grade-level group? (d) For lower and upper elementary readers, does base-word frequency contribute significantly to speed and accuracy of reading low-frequency derived words?

\section{Method}

\section{Participants}

Two groups of students were included-an upper elementary group, consisting of $33 \mathrm{fifth}$ and sixth graders ( 9 boys, 24 girls) and a lower elementary group, made up of 39 second and third graders (21 girls, 18 boys). The students were participants in a research project focused on the reading of derived words by poor readers as compared to chronologicalage and reading-age matched groups (Carlisle \& Stone, 2003). They attended suburban schools near a large, midwestern U.S. city.

The performance of the two groups on standardized measures of reading and vocabulary is summarized in Table 1. The students were given the 1989 Woodcock-Johnson Psychoeducational Battery-Revised, Letter-Word Identification (LWID) and Word Attack (WA) subtests and the 1997 Peabody Picture Vocabulary Test, 3rd edition, a measure of receptive vocabulary. To be included in this study, a student had to have a standard score on the PPVT of 80 or above and a standard score on the LWID measure of 90 or above. The groups did not differ on grade-level standard scores for these measures. In addition, there were no statistically significant differences on these measures for the boys and girls in each of the grade-level groups $(p>.05)$.

\section{Materials}

Students were given a computer-administered, word-reading task with a variety of types of words presented in different sets. The students were asked to read aloud (a) high-frequency derived and matched pseudoderived words and (b) low-frequency derived words. The computer battery also included a reaction time task.

Reaction time task (adapted from Cisero, Royer, Marchant, \& Jackson, 1997). For this task, a student was asked to name randomly presented nonverbal stimuli. Each trial consisted of one of two symbols (* or + ) printed three times in the center of the computer screen. In the training items, a student was asked to call *** "star" and +++ "plus." The purpose was to assess students' speed of naming written nonverbal symbols to determine whether naming speed of nonverbal stimuli was significantly different for the two groups. If this were the case, it would be important to control for nonverbal naming speed in the analysis of speed of word reading. A computer removed aberrant reaction times (those that were greater than 2 standard deviations from that student's mean) during the calculation of the mean for each task.

Word-reading task. The student read words presented on the computer screen. One measure involved reading high-frequency derived and pseudoderived words, and the other involved reading low-frequency derived words. Each of these is described below.

(1) High-frequency derived and pseudoderived words. Because the students spanned grades 2 through 6, we selected familiar derived forms for this

\section{TABLE 1}

\section{MEAN STANDARD SCORES OF LOWER AND UPPER ELEMENTARY GROUPS ON STANDARDIZED READING AND VOCABULARY MEASURES}

\begin{tabular}{lccc} 
Student group & LWID & WA & PPVT \\
\hline Lower elementary & 111.0 & 106.3 & 100.8 \\
& $(13.8)$ & $(15.7)$ & $(15.2)$ \\
Upper elementary & 109.4 & 106.0 & 105.8 \\
& $(11.0)$ & $(16.2)$ & $(14.6)$
\end{tabular}

Note. LWID = 1989 Woodcock Johnson Letter-Word Identification; WA = 1989 Woodcock Johnson Word Attack; PPVT = Vocabulary (1997 Peabody Picture Vocabulary Test, 3rd ed.); SDs are given in parentheses. 
task. Our choice of words was also constrained by difficulties finding one-morpheme words that could be matched to derived forms on word frequency, spelling, and word length. Of the 24 target words, 12 were derived forms, including 6 nouns ending with -er (e.g., winner) and 6 adjectives formed by adding the suffix $-y$ to a noun (e.g., windy). All of the words contained two syllables. Average word length was 5.2 letters $(.8 S D)$, average word frequency was $49.6(4.4 S D)$, and mean base frequency was 54.9 (6.7 SD). These frequencies are logarithmic transformations of the frequency of words in written texts through grade 9, called the Standard Frequency Index (SFI); a value of 50 indicates that a word appears once in 100,000 words of text (Carroll, Davies, \& Richman, 1971). The 12 pseudoderived words were matched as closely as possible to the derived forms in spelling, word length, and frequency (e.g., dinner matched to winner). All words contained two syllables. Average word length was 5.4 letters $(.8$ $S D$ ), and surface frequency was 54.2 (6.1 SD). The target words are listed in Appendix A. We added 26 filler words to decrease the likelihood that readers would notice the suffix pattern of the target words; these included 11 inflected words (e.g., grabbed), 11 one-syllable words (e.g., nest), and 4 three-syllable words (e.g., elephant).

(2) Low-frequency derived forms. Students named 23 low-frequency derived words that are phonologically and orthographically transparent and that have high-frequency base words (e.g., queendom, puzzlement). The words are listed in Appendix A. The base-word frequency (SFI) was comparable to that of the high-frequency derived words in the preceding task (mean $=55.1, S D=3.6)$. However, there was a greater variety of suffixes on these low-frequency words. Average word length was 8.1 letters (1.2 $S D)$; average number of syllables was $2.7(.6 S D)$. The average word frequency was 33.2 (1.6 SD).

\section{Procedures}

Students were given the standardized tests individually in one session lasting about 20 minutes. The experimental word-reading tasks were administered in a separate session, which lasted about 25 minutes. For these tasks, a student was seated in front of a computer screen at a comfortable viewing distance. He or she wore a pair of headphones with a microphone that was attached to a voice-activated relay and a computer that calculated the student's response latencies. The student was given a brief introduction to using the computer for the reading tasks. The first task involved naming the nonverbal stimuli. The di- rections for this task introduced the student to the general procedures for all of the tasks. When one of these symbols (and in other tasks, a word) appeared on the screen, the student named it. Immediately after the student vocalized a response, feedback on the accuracy of the response (input by the examiner, using a button box) appeared in the top right corner of the screen. The purpose of the feedback was to encourage accuracy over speed. Appropriate practice items followed these directions. The reading of highfrequency words preceded the reading of low-frequency derived words. The computer program randomly selected the order of the words in each task. If at any time the student read six words incorrectly in a row, the examiner stopped the administration of that set. If a student did not respond at all to a word within about five seconds, the examiner asked the student to move on to try the next word. Lack of response was coded as missing data, distinguished therefore from students' incorrect responses.

Response latencies to both correctly and incorrectly named words were included so that the performance of groups could be compared on the basis of responses to the same number of words of each type. If latencies for only accurate responses were analyzed, the lower elementary readers' response times would likely be based on their reading of fewer words and easier words than were read by the upper elementary students.

\section{Results}

\section{Performance on real and pseudoderived words}

The first question concerned the speed and accuracy of reading real and pseudoderived words by the lower and upper elementary students. Analysis of performance on the reaction time task showed that the upper elementary students were statistically significantly faster at reading the nonverbal stimuli than the lower elementary students, $t(70)=2.43, p<$ .05 , as shown in Table 2 . Because of this significant difference in naming speed, we examined the effects for word reading with and without performance on the reaction time task as a covariate. The results of the two sets of analyses were the same. We report the results without the covariate.

Table 2 also shows the performances of the groups on the derived and pseudoderived words. Two ANOVAs with one between-subjects factor (gradelevel groups) and one within-subjects factor (derived and pseudoderived words were conducted); the dependent variables were accuracy and speed of naming. For accuracy, results showed that the interaction 
TABLE 2

PERFORMANCE ON REACTION TIME, DERIVED WORD, PSEUDODERIVED WORD, AND LOW-FREQUENCY WORD TASKS

\begin{tabular}{|c|c|c|c|c|c|c|c|}
\hline \multirow[b]{2}{*}{ Group } & \multirow{2}{*}{$\begin{array}{c}\text { Reaction time } \\
\text { Speed }\end{array}$} & \multicolumn{2}{|c|}{$\begin{array}{l}\text { High-frequency } \\
\text { derived words }\end{array}$} & \multicolumn{2}{|c|}{$\begin{array}{l}\text { High-frequency } \\
\text { pseudoderived words }\end{array}$} & \multicolumn{2}{|c|}{$\begin{array}{c}\text { Low-frequency } \\
\text { transparent derivations }\end{array}$} \\
\hline & & Accuracy & Speed & Accuracy & Speed & Accuracy & Speed \\
\hline Lower elementary & $\begin{array}{l}.91 \\
(.30)\end{array}$ & $\begin{array}{c}79.3 \\
(17.5)\end{array}$ & $\begin{array}{c}1.73 \\
(1.13)\end{array}$ & $\begin{array}{l}72.9 \\
16.4\end{array}$ & $\begin{array}{c}2.00 \\
(1.20)\end{array}$ & $\begin{array}{l}52.69 \\
(24.14)\end{array}$ & $\begin{array}{c}3.31 \\
(2.26)\end{array}$ \\
\hline Upper elementary & $\begin{array}{l}.76 \\
(.21)\end{array}$ & $\begin{array}{l}95.2 \\
(6.6)\end{array}$ & $\begin{array}{l}.86 \\
(.21)\end{array}$ & $\begin{array}{l}86.7 \\
(8.3)\end{array}$ & $\begin{array}{c}.93 \\
(.27)\end{array}$ & $\begin{array}{l}81.07 \\
(9.42)\end{array}$ & $\begin{array}{l}1.52 \\
(.58)\end{array}$ \\
\hline
\end{tabular}

was not statistically significant, $F(1,70)=.56, p=$ .46. There was a statistically significant effect for group, $F(1,70)=27.26, p<.001$ (partial eta squared of .28), and a statistically significant effect for morphemic structure, $F(1,70)=26.68, p<.001$ (partial eta squared of .28). As Table 2 shows, both groups were more accurate on the real than the pseudoderived words, and the upper elementary students were more accurate in general than the lower elementary students. For speed, results showed that the interaction was not statistically significant, $F(1,70)=$ $2.53, p=.12$. There was a statistically significant effect for group, $F(1,70)=20.09, p<.001$ (partial eta squared of .26), and for morphemic structure, $F(1$, $70)=8.52, p<.01$ (partial eta squared of .11).

Because the interaction approached significance, post-hoc analysis (Tukey's HSD for unequal sample sizes) was carried out. The results showed that the lower elementary students were significantly faster on the derived than the pseudoderived words, whereas for the upper elementary students speed of reading the two word types did not differ significantly.

Because differences in word length or word frequency can influence word reading, we examined performance on pairs of words (e.g., robber and rubber), taking into consideration the number of letters and the $\log$ frequency. Only 4 of the 12 pairs differed in word length. For 3 of these, the pseudoderived word was longer by 1 or 2 letters, yet the students read the derived word more accurately, whereas the derived word was longer by 2 letters for the fourth pair, and the pseudoderived word was read more accurately. For the remaining 8 pairs, which had the same number of letters, the derived word was read more accurately for 5 of the pairs, and the pseudoderived word was read more accurately for 3 of the pairs. Thus, shorter words in the word pairs were consistently read more accurately than longer words. For pairs made up of words of equal length, the derived word was more often read correctly than the pseudoderived word.

In terms of frequency, the derived form had a higher $\log$ frequency than the other member of its pair for only 2 of the 12 pairs. For both of these pairs, the derived word was read more accurately than the pseudoderived word. In 7 of the remaining 10 pairs, all of which had higher frequency pseudoderived than derived forms, the derived form was read more accurately than the pseudoderived form. Thus, the member of the pair that was less common (the derived form) was more often read correctly than the member that was more common (the pseudoderived word). In short, analysis of performance on individual pairs of words matched for spelling and sound indicated that neither word length nor frequency accounted for the greater accuracy on derived as compared to the pseudoderived words.

\section{Performance on low-frequency derived words}

The second question concerned lower and upper elementary students' speed and accuracy of reading low-frequency derived words. Performance on these words is shown in Table 2. The performance of two students who were unable to complete this task was not included.

First, students' performance on high- and lowfrequency derived words was compared. This analysis was carried out because we had tried to select unfamiliar words for the low-frequency word set, and we wanted to make sure that reading of these words was 
less accurate and slower than reading of the highfrequency words. Two ANOVAs with one betweensubjects factor (the two grade-level groups) and one within-subjects factor (low- and high-frequency derived words) were conducted; the dependent variables were accuracy and speed of naming. Results for accuracy showed a statistically significant interaction, $F(1,68)=39.06, p<.001$ (partial eta squared of .36). There was also a statistically significant effect for group, $F(1,68)=39.18, p<.001$ (partial eta squared of .37) and for word type, $F(1,68)=$ $855.68, p<.001$ (partial eta squared of .93). Posthoc analysis showed a greater difference on highversus low-frequency derived words for the lower elementary than for the upper elementary students. In terms of speed, the results showed a statistically significant interaction, $F(1,68)=11.69, p<.001$ (partial eta squared of .15); a statistically significant effect for group, $F(1,68)=20.51, p<.001$ (partial eta squared of .23); and a statistically significant effect for word type, $F(1,68)=71.40, p<.001$ (partial eta squared of .51). Post-hoc analysis showed the same pattern of results as was found for accuracy.

The purpose for including the low-frequency derived words was to determine whether the highfrequency base words contained in these words (e.g., queen in queendom) influenced the facility and accuracy with which the students read the unfamiliar words. To answer this question, we carried out a standard regression analysis designed to show the extent to which base-word frequency and word length accounted for variance in the accuracy and speed of reading the low-frequency derived words. Separate analyses were carried out for each grade-level group. The unit of analysis was the word; the dependent variable was either accuracy or speed of reading the low-frequency derived words. The independent variables were the frequency of the base word and the number of syllables in the word. The results are shown in Table 3.

For the lower elementary group, the results showed that the two predictor variables jointly accounted for $51 \%$ of the variance in the speed of word reading (adjusted R-square of .46), $F(2,20)=$ $10.26, p<.001$. However, only the number of syllables contributed significantly to word-reading speed. For accuracy of word reading, the two variables accounted for $55 \%$ of the variance (adjusted R-square of .50), $F(2,20)=12.14, p<.001$. Again, only the number of syllables made a statistically significant contribution. For the upper elementary group, the results showed that the two variables accounted for $39 \%$ of the variance in reading speed (adjusted Rsquare of .33), $F(2,20)=6.36, p<.001$. Syllables again made the only statistically significant contribution. For accuracy of reading, the variables accounted for $53 \%$ of the variance in word-reading accuracy (.48 adjusted R-square); both syllables and the base frequency contributed significantly to the equation, $F(2,20)=11.19, p<.001$.

\section{TABLE 3}

\section{CONTRIBUTION OF WORD LENGTH AND BASE FREQUENCY TO SPEED AND ACCURACY OF READING LOW-FREQUENCY TRANSPARENT DERIVED WORDS}

\begin{tabular}{|c|c|c|c|c|}
\hline Lower elementary & Beta & Standard error of Beta & $t$-value & $p$-level \\
\hline \multicolumn{5}{|l|}{ Speed } \\
\hline Syllables & .71 & .16 & 4.52 & .000 \\
\hline Base frequency & -.004 & .16 & -.03 & .979 \\
\hline \multicolumn{5}{|l|}{ Accuracy } \\
\hline Syllables & -.73 & .16 & 4.84 & .000 \\
\hline Base frequency & .20 & .16 & 1.29 & .210 \\
\hline \multicolumn{5}{|l|}{ Speed } \\
\hline Syllables & .62 & .17 & 3.55 & .002 \\
\hline Base frequency & -.11 & .17 & .66 & .520 \\
\hline \multicolumn{5}{|l|}{ Accuracy } \\
\hline Syllables & -.61 & .15 & 3.95 & .000 \\
\hline Base frquency & .45 & .15 & 2.92 & .008 \\
\hline
\end{tabular}




\section{Relation of derived word reading to word identification}

Pearson correlations were calculated as a way to determine whether performance on the experimental word-reading tasks was related to achievement in word reading and word attack. As Table 4 shows, for both groups, LWID was significantly related to speed and accuracy of reading low-frequency derived words, and WA was significantly related to accuracy of reading these words. For lower elementary students, reading high-frequency derived and pseudoderived words was significantly related to performance on LWID and WA, but no such relation was evident for the upper elementary students. One reason for the lack of significant relations for the upper elementary students might be the relatively limited range of variation in accuracy and speed of reading the high-frequency words (see Table 2 ).

\section{Discussion}

The purpose of study 1 was to determine whether students' reading of transparent derived words suggested sensitivity to morphemic units. Specifically, we asked whether two-syllable words made up of two familiar morphemes (e.g., shady) were read more accurately and rapidly than twosyllable words made up of one morpheme (e.g., lady). Furthermore, performance on phonologically and orthographically transparent derived words provided a basis for determining whether morphological processing is evident for upper but not lower elementary readers, as Adams (1990) suggested.
The results showed that both lower and upper elementary readers were more accurate at reading transparent derived words (e.g., shady) than pseudoderived words (e.g., lady), matched on spelling, word length, and word frequency. The lower elementary students were also faster at reading the derived words than the pseudoderived words. Although familiar morphemes might function as orthographic patterns, as Ehri (1998) suggested, results indicate that recognition of common base morphemes in the derived words facilitated word reading. Because this suggestion is based on the likelihood that morphemic structure was the only systematic difference between word pairs such as shady and lady, it seemed important to determine whether word length or frequency might have differentially affected reading of derived or pseudoderived words. Analysis of performance on pairs (e.g., shady and lady) indicated that although word length and frequency are factors known to influence word reading, neither word length nor frequency accounted for the greater accuracy on derived words (as compared to pseudoderived words). However, because differences in word length and frequency of pairs were minimal (e.g., 8 of the 12 pairs were identical in length), these results are limited in the extent to which they are applicable to performance on all derived words.

A more stringent test of the possibility that familiar morphemes within words facilitate word reading would involve examining response latencies for only those pairs of words in which both members were read accurately. However, it was not advisable to carry out this analysis in this study, as accuracy patterns were quite variable for both lower and upper elementary students. In particular, the lower

\section{TABLE 4}

\section{CORRELATION OF EXPERIMENTAL WORD-READING MEASURES AND STANDARDIZED READING MEASURES FOR LOWER ELEMENTARY AND UPPER ELEMENTARY GROUPS}

\begin{tabular}{|c|c|c|c|c|c|c|}
\hline & \multicolumn{2}{|c|}{ High-frequency derived } & \multicolumn{2}{|c|}{ High-frequency pseudoderived } & \multicolumn{2}{|c|}{ Low-frequency derived } \\
\hline & Accuracy & Speed & Accuracy & Speed & Accuracy & Speed \\
\hline \multicolumn{7}{|c|}{ Lower elementary } \\
\hline LWID & $.59^{* * *}$ & $-.51^{* *}$ & $.39^{*}$ & $-.44^{* *}$ & $.73^{* * *}$ & $-.48^{* *}$ \\
\hline WA & $.48^{* *}$ & -.28 & $.48^{* *}$ & -.22 & $.71^{* * *}$ & $-.25^{*}$ \\
\hline \multicolumn{7}{|c|}{ Upper elementary } \\
\hline LWID & .16 & -.14 & .18 & -.13 & $.74^{* * *}$ & $-.40^{*}$ \\
\hline WA & -.14 & -.05 & .33 & .04 & $.48^{* *}$ & -.08 \\
\hline \multicolumn{7}{|c|}{ Note. LWID = Letter-Word Identification; WA = Word Attack. } \\
\hline
\end{tabular}


elementary students showed low percentages of accuracy on word pairs. For example, second graders read both lady and shady correctly only $31 \%$ of the time. In future studies, examination of response latencies for pairs of words read correctly would be one way to determine whether derived words made up of familiar base morphemes facilitate word reading.

The results provide a basis for reconsidering the roles of syllables and morphemes in current models of the acquisition of word-reading skills. For example, Schlagal's (1992) stage model has words of two as well as one morpheme in the stage of learning to read two-syllable words (e.g., maple and gunner), but our results suggest that the syllabic structure is not the only characteristic of words that students respond to in this stage. If the results of this study are representative, morphemic structure also makes a significant difference. The effect sizes for morphemic structure were small, but they nonetheless point to a reliable role in word reading.

The upper elementary students' reading of the high-frequency words showed that with experience comes increasing facility, as the difference between derived and pseudoderived forms was less pronounced for this group than for the lower elementary students. The upper elementary students read both the one- and two-morpheme words in less than a second, on average, with high rates of accuracy (87\% correct for pseudoderived and $95 \%$ for real derived words). In contrast to the high-frequency derived words, for both groups, reading the low-frequency derived words was not automatic, even though the base forms were high frequency and presumably familiar. Reading these words took over three seconds, on average, for the lower elementary group. Even the upper elementary students were less accurate and slower on the low-frequency derived words. This finding is in accord with the reported effects of word frequency and word length on word reading (e.g., Frederiksen \& Kroll, 1976).

We examined the reading of the low-frequency derived forms further to determine whether the familiar base words in these derived words contributed to speed and accuracy of reading. Analysis of the contribution of word length and base-word frequency showed that only word length was significant for the lower elementary readers. For upper elementary students, both word length and the base frequency contributed significantly to the accuracy of word reading, whereas only word length contributed to speed. For the upper elementary students, the highfrequency base words (e.g., star in stardom) appear to facilitate reading of unfamiliar words. However, the high-frequency base words were not a source of sup- port for the lower elementary readers, perhaps because of their inexperience in reading long and unfamiliar words. These results are consistent with findings reported by Mann and Singson (2003).

Finally, we examined the relation between reading derived words and performance on standardized measures of word reading, as these might reflect language and reading knowledge that students brought to the task of reading derived words (Seymour, 1997). The results showed significant relations between reading derived words and general wordreading skills, similar to results reported by others. For lower elementary students, the correlation between word reading (Word Identification subtest) and reading high-frequency derived words was .59; for low-frequency derived words, it was .73. For the upper elementary students, performance on the lowfrequency words was significantly related to general word-reading ability $(r=.74)$. The results are similar from those reported by Mahoney, Singson, and Mann (2000); they too found a moderately strong correlation (.51) between standardized word reading and performance on an oral and written morphological relatedness test for students in grades 3 through 6 .

\section{Study 2}

Study 1 focused exclusively on reading derived words that are transparent in spelling and sound. A second test of the hypothesis that morphemic structure affects word reading would involve comparison of performance on derived words that are phonologically transparent and those that are not. Previous research has shown that reading words that undergo phonological shifts presents a challenge for students learning to read (e.g., Carlisle, 2000; Mann \& Singson, 2003). Such shifts might include changes in the pronunciation of the vowel or in the syllable that is stressed, both of which are apparent in the shift from major to majority. If shift words such as majority are read more slowly or less accurately than stable words, such as maturity, we would have additional evidence that an important characteristic of morphemic structure affects the reading of derived words. In order to draw conclusions about possible differences in reading shift and stable derived words, such words must be matched on other characteristics that might contribute to differences in performance. These include spelling, word length, base-word frequency, and derived-word frequency. Other researchers have found production latencies to be longer for derived words that undergo phonological shifts, as compared to those that retain the sound 
structure of the base word (e.g., MacKay, 1978). Words transparent in structure are more likely to be processed with regard to their morphemic composition than words lacking phonological transparency (e.g., Carlisle, 2000; Champion, 1997; Leong, 1989; Tyler \& Nagy, 1989). However, even though these studies compare performance on derived words with and without phonological shifts, they do not provide direct evidence that changes in the phonological representation of derived words lead to differences in performance on shift and stable words.

One additional aspect of study 2 concerned the role of orthographic transparency. Because the effect of phonological opacity might be offset by orthographic transparency, as suggested by Templeton and Scarborough-Franks (1985), we selected words with and without phonological shifts that did not undergo orthographic changes as well. If researchers (e.g., Seymour, 1997) are correct in positing that orthography signals the identity of morphemes in words, even when there are sound shifts, we might find that derived words with and without phonological shifts are read with similar levels of accuracy and speed, particularly for high school students.

Because of the potential role of spelling in recognition of morphemes in derived words, we thought it was important to look at the effects of transparency on a lexical decision task, which does not require pronunciation of words aloud. Lexical decision requires indicating whether a string of letters is or is not a word; the nature of the task is such that it might not require the kind of thorough phonological processing that is needed for reading the word aloud. It seemed possible that transparency would affect reading of complex words but not lexical decision for these same words.

The research questions were as follows: (a) Do middle school and high school students differ in the accuracy and speed of reading derived words without transparent phonological structure (shift words), but not words with transparent structure (stable words)? (b) Do middle and high school students differ in accuracy and speed of recognizing words, depending on whether the words do or do not undergo a phonological shift?

\section{Method}

\section{Participants}

The participants were students attending middle and high schools. These students participated in a research project focused on the word reading of poor readers and their normally achieving reading peers (Carlisle et al., 2001). The middle school group included 15 students, 9 males and 6 females, between 10 and 12 years of age (mean age of 11.9). The high school group included 18 students, 9 males and 9 females, between 13 and 15 years of age (mean age of 14.5). Table 5 shows students' performance on standardized measures of reading, including word reading (Reading subtest, 1993 Wide Range Achievement Test, 3rd ed.[WR]), decoding (WA subtest, 1987 Woodcock Reading Mastery Test-Revised), and receptive vocabulary (PPVT). All students had WR standard score of 90 or above and a PPVT standard score of 80 or above. The middle and high school students did not differ on two of the measures when standard scores were based on gradelevel norms: for WR, $t(31)=.98, p=.34$; for PPVT, $t(31)=.83, p=.41$. They did differ on WA, $t(31)=$ $3.15, p<.01$. There were no significant differences in the performance of boys and girls on the standardized or the experimental reading measures.

\section{Materials}

Three computer-administered tasks were used in this study. Each is described as follows.

TABLE 5

PERFORMANCE ON STANDARDIZED MEASURES BY MIDDLE AND HIGH SCHOOL STUDENTS

\begin{tabular}{lccc} 
Student Group & WR & WA & PPVT \\
\hline Middle school & 100.0 & 102.5 & 110.3 \\
& $(7.0)$ & $(7.6)$ & $(12.5)$ \\
High school & 97.7 & 94.4 & $(106.6$ \\
& $(6.4)$ & $(6.4)$ & $(12.5)$ \\
\hline Note. Numbers in parentheses are standard deviations; WR = Letter-Word Identification; WA = Word Attack; PPVT = Vocabulary
\end{tabular}


Reaction time task. The students were given the same reaction time task as in study 1 .

Word-reading task. Students were asked to read words that appeared on the computer screen. The target words were derived words that differed in phonological transparency. Words lacking in phonological transparency (shift words) consisted of 13 derived words that undergo a phonological shift in the base word with the addition of the suffix (e.g., nature-natural, major-majority). The phonologically transparent words are referred to as stable derived words; these consisted of 13 derived words without a phonological shift between the base and derived word (e.g., cultural, maturity). These two word groups were matched for type of suffix (i.e., -al, -ity, -ence, -ce, or -tion), orthographic transparency, number of syllables (3.62 for shift and 3.46 for stable words), base-word log frequency (SFI of 49.08 for shift and 50.28 for stable), and derived-word log frequency (SFI of 43.90 for shift and 44.92 for stable) (Carroll, Davies, \& Richman, 1971). See Appendix A for a complete list of the target words. An additional 19 derived words (e.g., suitable) were used as fillers to reduce the likelihood that participants would notice patterns in word endings. These were comparable to the target words in length and frequency but different in the variety of suffixes on the words (e.g., -ly, -able, -ful); several were shift words.

Lexical decision task. The students were asked to indicate whether the letter string that appeared in the center of the computer screen was or was not a word. The target items were the same shift and stable words as on the word-reading task. The real-word foils on this task were the same 19 words as on the reading task. In addition, there were 40 nonwords, all of which had common suffixes (e.g., $-i c$ ) and were comparable in word length to the target words (3-4 syllables, $M=3.5)$. One half of the nonwords were legal nonwords, in that they conformed to English spelling and pronunciation (e.g., hodropic). The other half were illegal nonwords, in that they violated English spelling and pronunciation (e.g., infsioble).

\section{Procedures}

Students took the standardized tests and completed the computer tasks in two sessions. The wordreading and lexical decision tasks were administered on different days; administration of the wordreading task always preceded the lexical decision task. The same procedures for administration of the reaction time and word-reading tasks were used as in study 1 . For the lexical decision task, students responded using a button box, allowing computer recording of both accuracy and response latency.

\section{Results}

\section{Word reading}

The groups did not differ on the response latencies of the reaction time task, $t(21)=.42, p=$ .18. As a result, it was not necessary to use this task as a covariate. The first question concerned differences in reading shift and stable words by the middle and high school students. Their performance on these measures is shown in Table 6. Two ANOVAs with one between-subjects factor (middle and high school groups) and one within-subjects factor (shift and stable words) were carried out, one with the dependent measure being accuracy and the other speed (response latencies).

\section{TABLE 6}

PERFORMANCE ON REACTION TIME, READING STABLE AND SHIFT DERIVED WORDS, AND LEXICAL DECISION TASKS

\begin{tabular}{|c|c|c|c|c|c|c|c|c|c|}
\hline \multirow{2}{*}{\multicolumn{2}{|c|}{$\frac{\text { Reaction tir }}{\text { School group }}$}} & \multicolumn{4}{|c|}{ Word reading } & \multicolumn{4}{|c|}{ Lexical Decision } \\
\hline & & \multicolumn{2}{|c|}{ Shift words } & \multicolumn{2}{|c|}{ Stable words } & \multicolumn{2}{|c|}{ Shift words } & \multicolumn{2}{|c|}{ Stable words } \\
\hline & Speed & Accuracy & Speed & Accuracy & Speed & Accuracy & Speed & Accuracy & Speed \\
\hline Middle & $\begin{array}{c}.74 \\
(.12)\end{array}$ & $\begin{array}{c}65.8 \\
(17.7)\end{array}$ & $\begin{array}{c}2.29 \\
(2.00)\end{array}$ & $\begin{array}{c}88.5 \\
(14.9)\end{array}$ & $\begin{array}{c}1.60 \\
(1.00)\end{array}$ & $\begin{array}{c}85.7 \\
(13.5)\end{array}$ & $\begin{array}{l}1.65 \\
(.80)\end{array}$ & $\begin{array}{c}89.1 \\
(12.1)\end{array}$ & $\begin{array}{l}1.40 \\
(.64)\end{array}$ \\
\hline High & $\begin{array}{l}.76 \\
(.14)\end{array}$ & $\begin{array}{c}74.9 \\
(16.6)\end{array}$ & $\begin{array}{l}1.21 \\
(.41)\end{array}$ & $\begin{array}{l}94.7 \\
(6.2)\end{array}$ & $\begin{array}{c}1.06 \\
(.24)\end{array}$ & $\begin{array}{c}90.5 \\
(12.3)\end{array}$ & $\begin{array}{l}1.24 \\
(.55)\end{array}$ & $\begin{array}{c}89.3 \\
(13.3)\end{array}$ & $\begin{array}{l}1.11 \\
(.43)\end{array}$ \\
\hline
\end{tabular}


For accuracy, the results showed that the interaction was not statistically significant, $F(1,31)=.18$, $p=.67$. There was a statistically significant effect for group, $F(1,31)=4.44, p<.05$ (partial eta squared of .13), and a statistically significant effect for word type, $F(1,49)=37.18, p<.001$ (partial eta squared of .55). Both student groups were more accurate on the stable words than the shift words. For speed, the results showed that the interaction was statistically significant, $F(1,31)=4.18, p<.05$ (partial eta squared of .12). There was a statistically significant effect for group, $F(1,31)=5.09, p<.05$ (partial eta squared of .14), and a statistically significant effect for word type, $F(1,31)=10.09, p<.01$ (partial eta squared of .25). Post-hoc analyses (Tukey's HSD for unequal $n$ ) showed that the high school students were faster than the middle school students on both word types. The interaction was attributable to the fact that the middle school students differed in speed of reading the word types, whereas the high school students did not.

As in the first study, we considered the possibility that differences in word length or frequency might explain performances on the pairs of words that were matched for spelling and pronunciation (e.g., maturity and majority). We carried out an analysis of word pairs, using responses of a random selection of 20 of the study participants. Results showed that whether the shift word in each pair had the same number of letters as the stable word $(n=$ $6)$, the shift word was longer $(n=2)$ or the shift word was shorter $(n=5)$, the performance on the stable words was more accurate and rapid than on the shift words. However, $t$-tests showed no significant differences in accuracy on words within pairs. In terms of speed of responding, significant differences were found for three pairs with words of the same number of letters; the only pair with a significant difference in response latencies that also differed in the number of letters was intensity and serenity, and here the longer word intensity was responded to more rapidly, being the stable word of the pair. The same pattern was evident in the analysis of the frequency of the pairs of shift and stable words. The member of the pair with higher frequency was not consistently read more accurately. For example, colonial has a higher frequency than classical, but students read classical more accurately than colonial (84\% correct versus $60 \%$ correct). The analysis indicated that word length and frequency did not account for students' tendency to read stable words more accurately and faster than shift words.

\section{Lexical decision}

The second research question concerned differences in speed and accuracy of responses to shift and stable words by middle and high school students on the lexical decision task. Performance on these measures is shown in Table 6. Two ANOVAs, each with one between-subjects factor (student groups) and one within-subjects factor (shift or table derived words), were carried out — one with the dependent measure of accuracy and the other speed (response latencies).

For accuracy, the results showed that the interaction was not significant, $F(1,31)=1.69, p=.20$. There were also no statistically significant main effects: for group, $F(1,31)=.38, p=.54$; for word type, $F(1,31)=.38, p=.54$. For speed, the results showed that the interaction was not statistically significant, $F(1,31)=1.48, p=.23$. There was a statistically significant effect for word type, $F(1,31)=$ $13.38, p<.001$ (partial eta squared of .30), but the effect for group was not statistically significant, $F(1$, $31)=2.89, p=.10$. Thus, both student groups responded to stable derived words much more quickly than shift derived words.

\section{Discussion}

The purpose of study 2 was to investigate the effects of phonological transparency on the reading of derived words. In addition, we investigated the possibility that the orthographic stability of morphemes, in the face of phonological shifts, might over time compensate for the challenge of reading derived words that undergo phonological shifts (Reichle \& Perfetti, 2003; Templeton \& Scarborough-Franks, 1985). The results showed that for middle and high school students, derived words with transparent phonological structure (e.g., classical) were read more accurately than words with phonological shifts between the base and derived forms (e.g., colonial). For the middle school group, the stable words were read more rapidly as well.

Two decisions about the design of the study might have affected the results, and our interpretations of the results are limited by these decisions. One of these involved our method of analyzing response latencies, which differs from that used in most studies of word naming and lexical decision. That is, we included latencies for items read or identified as words both correctly and incorrectly. We used this method because our grade-level groups were likely to have different levels of accuracy on the words. If latencies for only accurately read words were analyzed, the middle school readers' naming 
speed and lexical decision would likely be based on fewer and easier items. This would make it difficult to interpret comparisons of naming speed for the two groups. In studies similar to ours, but with adults as participants, it is common practice to drop subjects whose accuracy falls below a conservative cutoff point (e.g., 10\%, as in Marslen-Wilson, Tyler, Waksler, \& Older, 1994). Such a practice would have resulted in the loss of many of the younger readers for analysis of response latencies in our study.

The second decision concerned the unit of analysis of the data. It was possible that the appropriate unit was the pairs of matched shift and stable words (for example, the shift word convention and the stable word confession). To address both limitations, we carried out a post-hoc analysis to compare the results of response latencies on the target words, contrasting the cases in which the response latencies were calculated for all words (right or wrong) or for matched pairs of shift and stable words read or identified correctly. The analysis was carried out with a random sample of 20 students (10 in each gradelevel group). The results of this analysis are shown in Appendix B. The slower of the response latencies for each pair of words is given in boldface print.

Three main points can be made, based on this analysis. First, for most of the pairs (9 out of 13), the shift word was read more slowly than the stable word, whether calculated for all items or just the pairs named correctly. For one pair (finality and conformity), the response latencies were almost identical for the two methods of scoring latencies. For the remaining pairs (natural and cultural, majority and maturity, confidence and dependence), the stable word was read more slowly. For all three of these pairs, the shift word was a more common word, and this might explain the faster response to it. However, we note that for some other pairs, the shift word was the more common word, and yet it still was read more slowly (e.g., convention and confession). Second, the responses to the pairs on the lexical decision task closely follow the pattern found on the word-reading task. This finding would seem to provide additional evidence that processing of words with complex phonological structures plays a role in visual word recognition, as others have suggested (Stolz \& Feldman, 1995; Templeton \& Scarborough-Franks, 1985). Third, we note that when latencies are analyzed for only correct reading of pairs of words, there were a number of instances in which only a small percentage of responses from the middle school readers could be included. For example, only 3 of the 10 middle school readers read the pair mortality and activity correctly, as compared to 6 of the high school students. Our post-hoc analysis of pairs read correctly or incorrectly generally shows the expected pattern of slower responses to shift words; nonetheless, focused as this is on only 20 students, further study of response latencies to derived words read correctly and incorrectly is warranted.

How might we explain the students' weaker performance on shift when compared to stable derived words? There are two likely reasons. One is that phonological shifts obscured the morphemic relations. A second is that the competing pronunciations of the base and derived forms interfered with accurate and rapid word reading. These are not mutually exclusive. Both might explain the poorer performance on shift words in the word-pair analysis described above. Shift words of the kind used in the tasks of this study represented a challenge to the middle school students, as is evident from the modest accuracy and slow speed of responding (on average, $65.8 \%$ correct in 2.3 seconds). In contrast, the high school students were more accurate and considerably faster at reading stable and shift words. On average, these words were read in a second. This performance approaches a word-reading speed that might be indicative of automaticity, but such an interpretation does not seem appropriate because the older students were noticeably less accurate on the shift words $(74.9 \%)$ than the stable words $(94.7 \%$ correct). Thus, speed in reading shift words may have been at the expense of accuracy. Overall, however, the results give evidence of an increased proficiency in reading derived words, phonologically transparent or not, between middle and high school.

As we had expected, phonological transparency appears to have had a lesser effect on the lexical decision than the word-reading task. Although a statistical comparison might be carried out to test differences in performance on the word-reading and lexical decision tasks, the constant order of presentation (word-reading before lexical decision) is a confound. Still, on the lexical decision task, middle and high school students identified stable and shift words with comparable levels of accuracy, with averages ranging from $85 \%$ to $90 \%$ correct, but both groups were faster at recognizing the stable words than the shift words. Here, too, is evidence that aspects of morphemic structure affect word identification.

What might explain the difference between middle and high school students in speed of recognizing shift and stable words? One possibility is that experience with written words leads high school students to recognize the orthographic constancy in the face of phonological change; middle school students might be more reliant on the phonological form 
than the high school students. This explanation is compatible with Reichle and Perfetti's (2003) proposal that with experience, mental representations of words have more extensive and interactive phonological, orthographic, and semantic foundations. These representations support rapid recognition (also fluent reading) of derived forms, even those characterized by complex phonological shifts.

\section{General discussion}

The studies reported herein were designed to determine whether morphemes in words affect word reading. Our first study was designed to determine whether morphemic structure affected elementary students' reading of two-syllable words. Because all of the words in this study were transparent in sound and spelling, the second study was designed to determine whether phonological transparency affected the accuracy and speed of reading or recognizing derived words that did or did not undergo phonological shifts. Here, too, we were seeking to determine whether phonological transparency was a characteristic of derived words that influenced accurate and fluent word reading.

\section{Is there a role for morphemes in word reading?}

What do the results of these two studies tell us about the reading of derived words by students at different grade levels? One finding is that even lower elementary readers appeared to make use of morphemic structure in reading derived words with transparent structure. Presented with words of two syllables, some with and some without suffixes, second and third graders read the words with suffixes more accurately and rapidly than the words without suffixes. An explanation that is compatible with current models of word reading is that segmentation of the derived words led to activation of mental representations of base words and suffixes (e.g., hill and $-y$ within hilly), which in turn facilitated speed and accuracy of word reading (Taft, 2003). One possible factor that might additionally explain this result is that the base word in common derived words (e.g., hill in hilly) tends to be more familiar (i.e., higher frequency) than the derived word (e.g., hilly). Thus, familiarity with both the base word and the suffix might have facilitated word recognition.

These results suggest that models of word reading, such as Ehri's (1998), might be adjusted to in- clude morphemes as well as familiar letter patterns as linguistic units that affect students' reading of multisyllabic words. The possibility that morphemic structure might influence the acquisition of wordreading skill as early as second or third grade presents a challenge to Adams's (1990) view that morphemic structure is a late-developing aspect of word reading. It could be argued that morphemic structure is less valuable for success in word reading in the early elementary years than other sources of information (e.g., syllable types), because young readers encounter relatively few complex words in the books they read. However, because exposure to complex words is the way in which children will build mental representations of morphemes (as well as free-standing words), by the end of the elementary years, the better word readers could be the ones who have acquired the most sensitivity to the morphemic structure of written words. As Mann and Singson (2003) pointed out, by the fifth grade, morphological awareness is a stronger predictor of reading than phonological awareness.

A second major finding arises from the fact that phonological transparency had a decided effect on middle and high school students' reading of derived words. Middle school students read $66 \%$ of the shift words correctly. For high school students, 75\% were read correctly. In contrast, $89 \%$ and $95 \%$ (respectively) of the stable words were read correctly. The results suggest that an emphasis on morphemic structure might be added to Schlagal's (1992) description of the challenges of the final stage of wordreading acquisition, which is characterized by learning complex letter-sound relations. Understanding morphemic structure at this stage involves complex mappings of the phonology and orthography of base and derived words.

The results of the two studies suggest that morphemic structure plays a role in reading derived words. For elementary students, familiar base words and suffixes facilitate word reading, when the morphemic structure is phonologically transparent. Upper elementary students were fast and accurate in reading high-frequency derived words like shady. For middle and high school students, reading derived words that have undergone phonological changes continues to be a challenge. However, the difference between phonologically stable and shift words diminishes somewhat by high school. Two factors might explain this result: experience with printed texts, which contain increasing numbers of derived words (Nagy \& Anderson, 1984), and the constancy with which the base morpheme is spelled in derived words. 
These two factors are related. The effects of transparency of morphemic structure are dependent on experience with derived words in written language. In study 1 , lower and upper elementary students read the low-frequency words more slowly and less accurately than the common derived words, and yet the base words in both word types were high frequency. Both the high- and low-frequency words were phonologically and orthographically transparent, but the morphemic structure of a transparent derived word might not be apparent when the reader has never seen that word before (as was likely for words like puzzlement). A third factor that emerged in study 1 as also influencing success in reading unfamiliar derived words was word length. In general, the longer the word, the longer the time it takes to formulate a pronunciation, a consistent finding in word-reading research. Clearly, the relative contributions of morphemic structure, transparency, and word length to accurate and fluent word reading need further study.

\section{Implications for further research and educational practice}

The role of morphemic structure in word reading is an area that has received relatively little attention from researchers concerned with acquisition of word-reading skill, particularly with regard to educational practices. Even though we found an effect for morphemic structure on derived word reading, we are limited in our ability to make generalizations about morphological processing of derived words because of the nature of the studies we have carried out. The participant groups were relatively small, and the experimental word-reading tasks were limited in the number of target items. Tasks such as the ones we devised are sensitive to variation in word characteristics (e.g., familiarity). Certainly replication of these studies is needed to determine whether the findings hold up with different groups of students and different sets of words.

Nonetheless, the results of our studies do suggest that further research on the effect of morphemic structure on word reading is worthwhile. We see potential value in seeking answers to several different questions. One is the effect of different types of transparency on reading of derived words. This would include phonology, orthography, and semantics - in different combinations, too. Semantic transparency has been shown to affect adults' perceptions of morphological relatedness (Marslen-Wilson et al., 1994). Complex relations of sound, spelling, and meaning of morphemes in words quite possibly influence word reading, but these are not well understood.

We also believe that it is important to examine students' reading of derived words in sentences or longer texts. Our tasks involved words read in isolation, and so the results bear only indirectly on natural reading of texts. It is likely that activation of semantic information varies when derived words are encountered in text passages. In keeping with this suggestion, we note again that Reichle and Perfetti's (2003) model of processing written words (both morphemically complex and simple) involves computations, leading to word identification that draws on knowledge of spellings, pronunciations, and meanings. They emphasized a characteristic they called lexical quality, defined as "the degree to which the orthographic, phonological, and semantic features that collectively define a given word are both well represented and well interlocked in the reader's memory" (p. 231). Understanding the interactive nature of phonological, orthographic, and semantic processing of derived words in natural texts is a critical research priority.

On the basis of the results of the studies reported here, we can see two educational implications. The first concerns the age or grade level at which it is appropriate to include explanation of the morphemic composition of words in a program of word-reading instruction. Given our findings, we do not agree with Adams's (1990) suggestion that teaching older readers about roots and suffixes of morphologically complex words might be "a worthwhile challenge," whereas "teaching beginning or less skilled readers about them may be a mistake" (p. 152). Adams pointed out that children's word recognition is affected by their familiarity with common spelling patterns and that syllable segments are more common than morphemic segments. She concluded, "To avoid conflicts with the goal of establishing solid sensitivity to frequent spelling patterns, instruction in morphology may best be postponed." The results of study 1 suggest that sensitivity to morphemes might reinforce or supplement sensitivity to letter patterns and syllables.

On the basis of their studies of morphological aspects of word reading and spelling, Treiman and Cassar (1996), Bryant, Nunes, and Bindman (2000), and Rubin, Patterson, and Kantor (1991) strongly recommended that elementary school teachers provide explicit instruction in word reading and spelling that links phonological, orthographic, syntactic, and morphemic elements. There are compelling reasons to attend to this recommendation. First, transparent aspects of morphemic structure are well within the 
grasp of elementary children; second, children can develop an awareness of morphemes and an implicit strategy of attending to patterns of morphemic structure as they learn new words (Carlisle \& Fleming, 2003). It is hard to dismiss the potential value of instruction in morphological awareness in the early elementary years. For this reason, it is gratifying to see that instruction focused on identification of base words and affixes has recently become a more common part of the elementary language arts curriculum.

The second educational implication is related to recent studies on teaching morphemic structure as a method of vocabulary building (e.g., Baumann et al., 2002). If students are going to be successful at inferring the meaning of derived words by analysis of morphemes (e.g., sub meaning "under," in submarine, subway), they first need to be able to read the words accurately. Accurate pronunciation provides access to information about the word in their oral vocabulary and a basis for establishing a phonological representation in memory. Combining analysis of morphemic structure for reading and inferring word meanings should be useful to students because of the increased prevalence of low-frequency but transparent derived words in texts (Nagy \& Anderson, 1984). The potential value of these combined strategies is supported by evidence that students can use morphemic structure to figure out the meanings of unfamiliar words (Anglin, 1993; Wysocki \& Jenkins, 1987).

Templeton (1989) has pointed out the importance of linking spelling, reading, and vocabulary instruction. Linking morphemic units (prefixes, suffixes, and base or root words) with an understanding of their semantic and syntactic roles provides ways to remember known words. Such links presumably support the development of strategies to analyze unfamiliar words that contain familiar morphemes. Combining instruction in morphemic units for purposes of both reading and vocabulary development inherently makes sense, as such instruction might provide the essential links between form and meaning that are the potential benefit of morphemic processing in the natural act of reading.

JOANNE F. CARLISLE is Professor of Educational Studies at the University of Michigan. Her research interests include the relationship between the acquisition of oral and written language, characteristics of effective literacy instruction for at-risk students in elementary schools, and effective models of professional development in reading for elementary teachers. She can be contacted at the School of Education, University of Michigan, 610 E. University Avenue, Ann Arbor, Ml 48109-1259, USA, or by e-mail at jfcarl@umich.edu.
C. ADDISON STONE is Professor of Educational Studies at the University of Michigan, where he currently serves as coordinator of the Literacy, Language, and Learning Disabilities unit and as Director of Graduate Studies for the Educational Studies Program. His research is focused on children and adolescents with language/learning disabilities, with a particular emphasis on the social context of atypical patterns of language and cognitive development. He can be contacted at the School of Education, University of Michigan, $610 \mathrm{E}$. University Avenue, Ann Arbor, Ml 48109-1259, USA, or via e-mail at addisons@umich.edu.

\section{REFEREN CES}

ADAMS, M.J. (1990). Beginning to read: Thinking and learning about print. Cambridge, MA: MIT Press.

ANGLIN, J.M. (1993). Vocabulary development: A morphological analysis. Monograph of the Society for Research in Child Development (Serial \# 238). Chicago: University of Chicago Press.

BAUMANN, J.F., EDWARDS, E.C., FONT, G., TERESHINSKI, C.A., KAME'ENUI, E.J., \& OLEJNIK, S.F. (2002). Teaching morphemic and contextual analysis to fifth-grade students. Reading Research Quarterly, 37, 150-176.

BROWN, G.D.A. (1998). The endpoint of skilled word recognition: The ROAR model. In J.L. Metsala \& L.C. Ehri (Eds.), Word recognition in beginning literacy (pp. 121-138). Mahwah, NJ: Erlbaum.

BRYANT, P., NUNES, T., \& BINDMAN, M. (2000). The relations between children's linguistic awareness and spelling: The case of the apostrophe. Reading and Writing: An Interdisciplinary Journal, 12, 253-276.

CARLISLE, J.F. (2000). Awareness of the structure and meaning of morphologically complex words: Impact on reading. Reading and Writing: An Interdisciplinary Journal, 12, 169-190.

CARLISLE, J.F., \& FLEMING, J. (2003). Lexical processing of morphologically complex words in the elementary years. Scientific Studies of Reading, 7, 239-253.

CARLISLE, J.F., \& STONE, C.A. (2003). The effects of morphological structure on children's reading of derived words. In E. Assink \& D. Santa (Eds.), Reading complex words: Cross-language studies (pp. 27-52). New York: Kluwer Academic.

CARLISLE, J.F., STONE, C.A., \& KATZ, L.A. (2001). The effects of phonological transparency on reading derived words. Annals of Dyslexia, 51, 249-274.

CARROLL, J.B., DAVIES, P., \& RICHMAN, B. (1971). Word frequency book. New York: American Heritage.

CHAMPION, A.H. (1997). Knowledge of suffixed words in reading and oral language contexts: A comparison of reading disabled and normal readers. Annals of Dyslexia, 47, 29-55.

CISERO, C.A., ROYER, J.M., MARCHANT, H.G., \& JACKSON, S.J. (1997). Can the computer-based academic assessment system (CAAS) be used to diagnose reading disability in college students? Journal of Educational Psychology, 89, 599-620.

EHRI, L.C. (1998). Grapheme-phoneme knowledge is essential for learning to read words in English. In J.L. Metsala \& L.C. Ehri (Eds.), Word recognition in beginning literacy (pp. 3-40). Mahwah, NJ: Erlbaum.

ELBRO, C., \& ARNBAK, E. (1996). The role of morpheme recognition and morphological awareness in dyslexia. Annals of Dyslexia, 46, 209-240.

FOWLER, A.E., \& LIBERMAN, I.Y. (1995). The role of phonology and orthography in morphological awareness. In L.B. Feldman (Ed.), Morphological aspects of language processing (pp. 157-188). Hillsdale, NJ: Erlbaum.

FOWLER, C., NAPPS, S., \& FELDMAN, L.B. (1985). Relations among regular and irregular morphologically related words in the lexicon as revealed by repetition priming. Memory and Cognition, 13, 241-255.

FREDERIKSEN, J.R., \& KROLL, J.F. (1976). Spelling and sound: Approaches to the internal lexicon. Journal of Experimental Psychology, 2, 361-379.

LEONG, C.K. (1989). Productive knowledge of derivational rules in poor readers. Annals of Dyslexia, 39, 94-115.

MACKAY, D.G. (1978). Derivational rules and the internal lexicon. Journal of Verbal Learning and Verbal Behavior, 17, 61-71.

MAHONEY, D., SINGSON, M., \& MANN, V. (2000). Reading ability and sensitivity to morphological relations. Reading and Writing: An Interdisciplinary Journal, 12, 191-218. 
MANN, V., \& SINGSON, M. (2003). Linking morphological knowledge to English decoding ability: Large effects of little suffixes. In E.M.H. Assink \& D. Sandra (Eds.), Reading complex words: Cross-language studies (pp. 1-25). New York: Kluwer Academic.

MARSLEN-WILSON, W., TYLER, L.K., WAKSLER, R., \& OLDER, L. (1994). Morphology and meaning in the English mental lexicon. Psychological Review, 101, 3-33.

NAGY, W.E., \& ANDERSON, R. (1984). How many words in printed school English? Reading Research Quarterly, 19, 304-330.

NAGY, W.E., \& ANDERSON, R., SCHOMMER, M., SCOTT, J.A., \& STALLMAN, A.C. (1989). Morphological families and word recognition. Reading Research Quarterly, 24, 262-282.

NAPPS, S.E. (1989). Morphemic relationships in the lexicon: Are they distinct from semantic and formal relationships? Memory and Cognition, 17, 729-739.

PERFETTI, C.A. (1992). The representation problem in reading acquisition. In P. Gough, L. Ehri, \& R. Treiman (Eds.), Reading acquisition (pp. 107-143). Hillsdale, NJ: Erlbaum.

REICHLE, E.D., \& PERFETTI, C.A. (2003). Morphology in word identification: A word experience model that accounts for morpheme frequency effects. Scientific Studies of Reading, 7, 219-237.

RUBIN, H., PATTERSON, P.A.S., \& KANTOR, M. (1991). Morphological development and writing ability in children and adults. Language, Speech, and Hearing Services in Schools, 2, 228-235.

SCHLAGAL, R.C. (1992). Patterns of orthographic development into the intermediate grades. In S. Templeton \& D. Bear (Eds.), Development of orthographic knowledge and the foundations of literacy: $A$ memorial festschrift for Edmund H. Henderson (pp. 31-52). Hillsdale, NJ: Erlbaum.

SCHREUDER, R., \& BAAYAN, R.H. (1995). Modeling morphological processing. In L.B. Feldman (Ed.), Morphological aspects of language processing (pp. 131-154). Hillsdale, NJ: Erlbaum.

SCHREUDER, R., GRENDEL, M., POULISSE, N., ROELOFS, A., \& VAN DE VOORT, M. (1990). Lexical processing, morphological complexity, and reading. In D.A. Balota, G.B. Flores d'Arcais, \& K Rayner (Eds.), Comprehension processes in reading (pp. 125-141). Hillsdale, NJ: Erlbaum.

SEYMOUR, P.H.K. (1997). Foundations of orthographic development. In C. Perfetti, L. Rieben, M. Fayol (Eds.), Learning to spell (pp. 319-337). Hillsdale, NJ: Erlbaum.

SINGSON, M., MAHONEY, D., \& MANN, V. (2000). The relation between reading ability and morphological skills: Evidence from derivational suffixes. Reading and Writing: An Interdisciplinary Journal, 12,
219-252.

STOLTZ, J.A., \& FELDMAN, L.B. (1995). The role of orthographic and semantic transparency of the base morpheme in morphological processing. In L.B. Feldman (ed.), Morphological aspects of language processing (pp. 109-129). Hillsdale, NJ: Erlbaum.

TAFT, M. (2003). Morphological representation as a correlation between form and meaning. In E.G.H. Assink \& D. Sandra (Eds.), Reading complex words: Cross language studies (pp. 113-137). New York: Kluwer Academic.

TAFT, M., \& ZHU, X. (1995). The representation of bound morphemes in the lexicon: A Chinese study. In L.B. Feldman (Ed.), Morphological aspects of language processing (pp. 293-316). Hillsdale, NJ: Erlbaum.

TEMPLETON, S. (1989). Tacit and explicit knowledge of derivational morphology: Foundations for a unified approach to spelling and vocabulary development in the intermediate grades and beyond. Reading Psychology, 10, 233-253.

TEMPLETON, S., \& SCARBOROUGH-FRANKS, L. (1985). The spelling's the thing: Knowledge of derivational morphology in orthography and phonology among older students. Applied Psycholinguistics, 6, 371-390.

TREIMAN, R., \& CASSAR, M. (1996). Effects of morphology on children's spelling of final consonant clusters. Journal of Experimental Child Psychology, 63, 141-170.

TYLER, A., \& NAGY, W.E. (1989). The acquisition of English derivational morphology. Journal of Memory and Language, 28, 649-667.

TYLER, A., \& NAGY, W. (1990). Use of derivational morphology during reading. Cognition, 36, 17-34.

VERHOEVEN, L., \& PERFETTI, C.A. (2003). The role of morphology in learning to read. Scientific Studies of Reading, 7, 209-217.

VERHOEVEN, L., SCHREUDER, R., \& BAAYAN, H. (2003). Units of analysis in reading Dutch bisyllabic pseudowords. Scientific Studies of Reading, 7, 2003, 255-271.

WINDSOR, J. (2000). The role of phonological opacity in reading achievement. Journal of Speech, Language and Hearing Research, 43, $50-61$.

WYSOCKI, J.K., \& JENKINS, J. (1987). Deriving word meaning through morphological generalization, Reading Research Quarterly, 22, $66-81$

Received June 27, 2003

Final revision received October 20, 2004

Accepted November 22, 2004 


\section{STUDY 1: TARGET WORDS ON EXPERIMENTAL READING TASK}

High-frequency derived

$\begin{array}{ll}\text { Real } & \text { Pseudo } \\ \text { icy } & \text { mercy } \\ \text { windy } & \text { candy } \\ \text { shady } & \text { lady } \\ \text { hilly } & \text { silly } \\ \text { dirty } & \text { empty } \\ \text { lucky } & \text { pretty } \\ \text { lover } & \text { hover } \\ \text { batter } & \text { chapter } \\ \text { robber } & \text { rubber } \\ \text { winner } & \text { dinner } \\ \text { beggar } & \text { flavor } \\ \text { mower } & \text { tower }\end{array}$

Low-frequency derived

$\begin{array}{ll}\text { Real } & \text { Pseudo } \\ \text { pailful } & \text { fearsome } \\ \text { bucketful } & \text { odorous } \\ \text { beastly } & \text { preventive } \\ \text { sparkly } & \text { observable } \\ \text { equalize } & \text { oddity } \\ \text { dramatize } & \text { wifelike } \\ \text { idealize } & \text { stylish } \\ \text { secretive } & \text { organist } \\ \text { corrective } & \text { valuation } \\ \text { flowery } & \text { puzzlement } \\ \text { cookery } & \\ \text { queendom } & \\ \text { stardom } & \end{array}$

\section{STUDY 2: TARGET WORDS ON THE EXPERIMENTAL TASKS}

$\begin{array}{ll}\text { Stable words } & \text { Shift words } \\ \text { cultural } & \text { natural } \\ \text { maturity } & \text { majority } \\ \text { security } & \text { severity } \\ \text { intensity } & \text { serenity } \\ \text { confession } & \text { convention } \\ \text { confusion } & \text { precision } \\ \text { conformity } & \text { finality } \\ \text { dependence } & \text { confidence } \\ \text { stupidity } & \text { sincerity } \\ \text { activity } & \text { mortality } \\ \text { oddity } & \text { locality } \\ \text { classical } & \text { colonial } \\ \text { difference } & \text { preference }\end{array}$


STUDY 2:

COMPARISON OF ACCURACY AND RESPONSE LATENCIES TO SHIFT AND STABLE WORDS IN PAIRS

\begin{tabular}{|c|c|c|c|c|c|c|}
\hline \multirow[t]{2}{*}{$\begin{array}{l}\text { Word } \\
\text { pair }\end{array}$} & \multicolumn{2}{|c|}{$\begin{array}{l}\text { Frequency } \\
\quad(\text { SFI) }\end{array}$} & \multicolumn{2}{|l|}{ Word reading } & \multicolumn{2}{|c|}{ Lexical decision } \\
\hline & & $\begin{array}{l}\text { Latencies } \\
\text { (correct or } \\
\text { incorrect) }\end{array}$ & $\begin{array}{c}\text { Percentage } \\
\text { pairs correctly } \\
\text { read }\end{array}$ & $\begin{array}{c}\text { Latencies } \\
\text { (correct } \\
\text { pairs) }\end{array}$ & $\begin{array}{l}\text { Percentage } \\
\text { pairs correctly } \\
\text { identified }\end{array}$ & $\begin{array}{c}\text { Latencies } \\
\text { (correct } \\
\text { pairs) }\end{array}$ \\
\hline${ }^{*}$ Natural & 61.3 & 1.18 & 95 & 1.09 & 80 & 1.12 \\
\hline Cultural & 47.6 & 1.45 & & 1.43 & & 1.27 \\
\hline *Majority & 52.6 & 1.67 & 85 & 1.16 & 85 & 1.27 \\
\hline Maturity & 45.3 & 1.73 & & 1.58 & & 1.44 \\
\hline *Severity & 31.7 & 2.83 & 35 & 1.10 & - & - \\
\hline Security & 49.1 & 1.58 & & .80 & & - \\
\hline *Serenity & 35.0 & 2.31 & 55 & 1.73 & 40 & 1.66 \\
\hline Intensity & 49.4 & 1.19 & & 1.40 & & 1.12 \\
\hline${ }^{*}$ Convention & 48.0 & 1.50 & 90 & 1.31 & 75 & 1.60 \\
\hline Confession & 31.9 & 1.28 & & 1.22 & & 1.35 \\
\hline${ }^{*}$ Precision & 49.0 & 1.87 & 80 & 1.39 & 60 & 1.16 \\
\hline Confusion & 51.4 & 1.05 & & 1.03 & & 1.13 \\
\hline *Finality & 34.0 & 1.63 & 45 & 1.85 & 35 & 2.21 \\
\hline Conformity & 32.5 & 1.69 & & 1.83 & & 1.56 \\
\hline${ }^{*}$ Confidence & 51.2 & 1.12 & 90 & 1.07 & 95 & 1.19 \\
\hline Dependence & 42.0 & 1.58 & & 1.15 & & 1.42 \\
\hline *Sincerity & 38.9 & 2.24 & 85 & 1.73 & 60 & 1.61 \\
\hline Stupidity & 38.2 & 1.17 & & 1.03 & & 1.33 \\
\hline${ }^{*}$ Mortality & 36.3 & 1.38 & 45 & .99 & 60 & 1.86 \\
\hline Activity & 54.3 & 1.36 & & .82 & & 1.35 \\
\hline${ }^{*}$ Locality & 39.6 & 2.10 & 40 & 1.21 & 40 & 1.86 \\
\hline Oddity & 33.9 & 1.34 & & 1.02 & & 1.35 \\
\hline${ }^{*}$ Colonial & 51.6 & 1.51 & 50 & 1.30 & 65 & 1.48 \\
\hline Classical & 47.3 & 1.07 & & .86 & & 1.13 \\
\hline *Preference & 41.4 & 1.18 & 85 & 1.10 & 85 & 1.31 \\
\hline Difference & 61.1 & .96 & & .89 & & 1.08 \\
\hline
\end{tabular}

Note. In each pair, the shift word is given first and is marked with an asterisk. Lexical decision data for the word security were lost in handling files, so that words in this pair could not be compared for this task. SFI= Standard Frequency Index. The longer response latency for each pair is in boldface print. 